\title{
TEOLOGIA DO QOHELET: UMA PROPOSTA
}

\author{
THEOLOGY OF QOHELET: A PROPOSAL
}

\author{
José Carlos Camillo Castro Neto ${ }^{1}$ \\ Jônatas de Mattos Leal ${ }^{2}$
}

\begin{abstract}
Resumo: O livro de Eclesiastes tem sido considerado um dos mais difíceis de ser interpretado nos estudos do Antigo Testamento. Prova disso são as inúmeras visões que os diversos estudiosos têm sobre esse livro. Ainda mais complicado se torna tentar entender o modo como o livro apresenta Deus. Este é o tema deste artigo. Para alcançar o objetivo de tentar entender como Deus é apresentado nesse livro enigmático, recorreu-se à revisão de literatura sobre o tema, bem como à exegese de várias passagens. Percebeu-se que duas visões são apresentados sobre Deus em Eclesiastes: uma de um Ser distante e incompreensível e outra de um Ser que atua pelo juízo. As duas visões são harmonizadas por características literárias do livro. Essa visão dupla e aparentemente paradoxal sobre a divindade aparece em outras partes do Antigo Testamento (AT), especialmente no corpus sapiencial da Bíblia Hebraica.
\end{abstract}

Palavras-chave: Eclesiastes; Teologia do Antigo Testamento; Literatura sapiencial

Abstract: The book of Ecclesiastes has been considered as one of the most difficult to be interpreted in the Old Testament's studies. That is why there are a lot of different scholar visions on that book. Yet more complicated is try to understand the way this book introduces God. That is the subject of the present paper. To reach the goal of understanding God in the book of Ecclesiastes, it was researched in scholars as well as the exegesis of several periscopes. It showed up two different visions of God in the enigmatic book: one of a distant and inscrutable Being another one of a Being who acts in the human history by the judgment. This two apparently different visions are harmonized by some literary features inside the book. This duo and apparently paradox vision on the divinity appears in others parts of the Old Testament (OT), especially in the wisdom corpus.

Keywords: Ecclesiastes; Old Testament Theology; Wisdom literature

\section{Introdução}

O presente artigo tem como objetivo principal examinar o modo como Eclesiastes, ou Qohelet, descreve a Deus. Este tema de estudo é importante porque os documentos do Antigo Testamento (AT) são reveladores da fé do povo de Israel no período anterior a Cristo e essa

\footnotetext{
1 Bacharel em Teologia pelo Seminário Adventista Latino-Americano de Teologia (SALT). josecarloscamillo@gmail.com

${ }^{2}$ Mestre em Ciências da Religião pela UNICAP, professor de línguas bíblicas e Antigo Testamento (SALT). lealjonatas@gmail.com
} 
fé, de maneira alguma, está desvinculada de seu Deus. Sendo esse livro de caráter tão debatido e com um tom tão amargo, descobrir a teologia ${ }^{3}$ de Eclesiastes nos ajudaria a entender melhor a fé de Israel no AT, a compreender melhor o livro em si e a termos uma visão espiritual da vida, como o livro ensina.

Para realizar nosso objetivo, iremos analisar o modo como Deus é apresentado no corpo do livro (1:2-12:8). Logo em seguida, analisaremos a maneira como Deus é descrito no epílogo. Por fim, procuraremos relacionar ambas as posições (corpo e epílogo) e também, relacionar a teologia de Eclesiastes com a teologia do restante do Antigo Testamento.

Chegaremos à conclusão que Qohelet apresenta duas visões sobre Deus: uma empírica (baseada no que o sábio podia perceber) e uma da fé (baseada no que o sábio confiava). Desse modo, esse livro sapiencial admite que é difícil entender o modo que Deus age, mas prega a confiança de que há um juízo que resolverá nossos problemas e esclarecerá o agir de Deus.

\section{Deus incompreensível - a teologia do corpo do livro (1:2-12:8)}

A primeira ideia importante que Qohelet tem de Deus é que Ele é um Ser distante, insondável e, aparentemente, arbitrário. É o que vamos passar a demonstrar nessa primeira parte do artigo.

Uma das evidências de que Qohelet vê a Deus como distante e insondável é o próprio nome que ele lhe dá. Deus é chamado, no livro de Eclesiastes, principalmente ${ }^{4}$, de אֶלהים, e

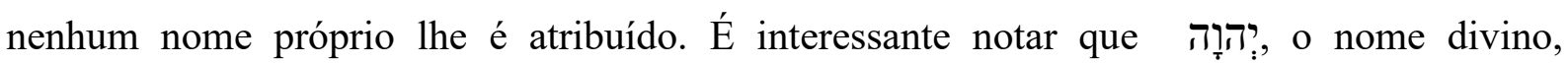
caracteriza o Deus da Aliança, o Deus que se relaciona com Seu povo (MOSKALA, 2011, p. 26), não é usado para se referir a Deus em nenhum lugar do livro. Ao contrário, aparece apenas אֶלהים, que, segundo Moskala (2011, p. 46, destaque nosso), “[...] refere-se a um Deus transcendente, poderoso, soberano e universal de toda humanidade." 5 .

Para que o leitor não pense que אֶלדֶים é qualquer Deus, Qohelet usa, preferencialmente, esse substantivo com o artigo, para definir, provavelmente, que ele está

\footnotetext{
${ }^{3}$ Quando se fala de teologia de um livro bíblico, pode-se referir aos temas teológicos tratados nele ou à sua maneira de ver e apresentar Deus. Vamos usar neste trabalho, apenas o segundo significado.

${ }^{4}$ Dois outros títulos prováveis a Deus aparecem no livro de Eclesiastes: Criador (12:1) e Pastor (12:11).

${ }^{5}$ Pode-se perceber uma influência egípcia no modo de fazer sabedoria em Eclesiastes, como muitos autores mostram. Desse modo, o fato de Qohelet usar apenas o substantivo "Deus" sem atribui-lo um nome próprio remete à cultura egípcia de, em textos sapienciais, não usar nome de Deus nenhum, mas apenas atribui-lo o substantivo genérico, "Deus" (SCHIMDT, 2004, p. 121). Isso não indica uma influência egípcia no conteúdo, mas sim na forma. E, também, não nega o fato de que foi uma escolha de Qohelet, provavelmente por motivos teológicos, o modo de chamar Deus em seu livro, já que no livro de Jó, que também apresenta influência egípcia, aparece o tetragrama sagrado.
} 
falando de um Deus específico. De fato, Qohelet é o escritor bíblico que mais utiliza, proporcionalmente, o substantivo אֶלה com o artigo. Das quarenta vezes que ele faz uso desse substantivo, em trinta (ou seja, 75\%) este é articular. O uso desse título divino, então, mostra, de certo modo, a distância, diferença, separação, entre Deus e o homem, pois é um nome impessoal. Além disso, mostra a universalidade do Deus de Qohelet. Este não escreve seu livro para um povo específico, seu pensamento abrange toda vida humana em qualquer época e em qualquer lugar (EATON, 1989, p. 37).

O fato de que Deus é visto por Qohelet como um Deus distante e insondável é evidenciado, também pela forma que ele estrutura seu livro. A estrutura desse livro enigmático tem sido proposta por diferentes pessoas, mas a proposta de Wright (1968, p. 313334) parece ser a melhor documentada e aparenta surgir do próprio texto ${ }^{6}$. Por isso, vamos utiliza-la neste trabalho.

Wright (1968, p. 321-322) mostra como a expressão "e eis que tudo é vaidade e correr

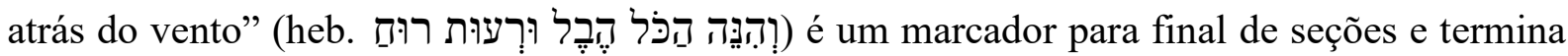
em Eclesiastes 6:9. Essa primeira parte do livro, que se divide em seis seções, tendo duas introduções, trata da vaidade da vida. Em especial, toca nos assuntos da procura pelo prazer, sabedoria e loucura e os frutos do trabalho. Uma das seis seções da primeira parte do livro é dedicada à busca pelo prazer (2:1-11), outra é dedicada à sabedoria e loucura $(2: 12-17)$ e as outras quatro tratam detalhadamente da vaidade do trabalho e da única coisa que se pode usufruir: seus frutos (2:18-26; 3:1-4:6; 4:7-16; 4:17-6:9) (WRIGHT, 1968, p. 321-322).

A razão para tal vaidade é apresentada na segunda parte do livro. A segunda parte do livro se propõe a responder às questões propostas em 6:10-12. Os capítulos 7-8 afirmam que o homem לא יוּכַל לִמְצָא (pt. não pode alcançar). Em outras palavras, Qohelet pergunta em 6.1012 quem pode saber o que virá acontecer ao homem e ele mesmo responde nos textos seguintes que ninguém pode alcançar esse conhecimento. O trecho de 9:1-11:6 afirma que אֶ

\footnotetext{
${ }^{6}$ Percebe-se que há uma dificuldade dos teóricos para encontrar uma linha de raciocínio inquebrável no livro de Eclesiastes, o que resulta numa dificuldade em encontrar sua estrutura. Cada comentário bíblico pesquisado para este trabalho defende uma estrutura diferente. Mas Wright (1968, p. 313-334) apresenta bons argumentos para sua própria estrutura. O primeiro argumento é o uso de expressões que servem como marcadores de finais de seção. Além disso, essas expressões-marcadores dividem o texto em seções lógicas, portanto são válidas. $\mathrm{O}$ segundo argumento é numérico. Wright (1980, p. 38-51) mostra que, assim como acontece com Provérbios, o livro de Eclesiastes foi organizado de maneira matemática. O livro tem 222 versos e a metade deles ocorre exatamente em 6:9-10, como a teoria de Wright mostrava. Ainda, a primeira parte do livro (2:1-6:9) contém 93 versos assim como a segunda (6:10-11:6). Outros argumentos numéricos foram mostrados pelo autor. Dillard e Longman III (2005, p. 240) discordam dessa proposta de estrutura, mas encontramos outros autores, como Murphy (1992, p. xxxix) que concordam com o estudo feito por Wright.
} 
עִִ̣i' (pt. não há quem conheça - não há conhecedor). Assim, a segunda parte do livro trata da falta de conhecimento do homem das obras de Deus e é isso que torna tudo vaidade.

Os padrões sugerem que o livro está dividido em duas partes principais (1:12-6:9; 6:10-11:6) e o pensamento também é dividido assim: na primeira parte Qohelet está preocupado com a vaidade de vários empreendimentos humanos, e na segunda parte, com a inabilidade do homem para entender a obra de Deus. (WRIGHT, 1968, p. 324 , grifo nosso). ${ }^{7}$

Compreendendo isso, percebemos que o tom cético e ácido que se vê especialmente na primeira parte do livro de Eclesiastes ocorre porque o homem não pode compreender as obras de Deus. Como afirma Wright (1968, p. 334, destaque do autor): “A ideia da impossibilidade de entender o que Deus tem feito (que sempre foi vista como um tema) é, na realidade, $o$ tema, e ele é construído na proeminente ideia de vaidade na primeira parte do livro." ${ }^{8}$. Desse modo, podemos entender que a estrutura de Eclesiastes aponta para o fato de que Qohelet vê a Deus como insondável. Um Deus transcendente que atua na história humana de maneira incompreensível. A seguir, analisaremos mais detalhadamente alguns textos em que essa ideia se faz mais presente.

\subsection{A insondabilidade de deus}

Uma primeira linha de textos mostra a insondabilidade de Deus ou, como Pinto (2006, p. 561) diz: a inescrutabilidade de Deus. São quatro textos que trazem a ideia de inescrutabilidade divina: $3.11,8.17,9.1$ e 11.5. O primeiro desses textos é o mais problemático. Eclesiastes 3.11 é chamado por Murphy (1992, p. 34) de crux interpretum. Mas a parte mais complicada não nos interessa agora ${ }^{9}$, que é a primeira parte. O que interessa a essa parte do estudo é a última parte do verso.

O v. 3.11b diz: "para que não alcance o homem a obra que faz Deus do princípio até o fim. ${ }^{\prime 10}$. Uma coisa se destaca nessa passagem: o homem não é capaz de alcançar a obra de

\footnotetext{
${ }^{7}$ Original em inglês: "The patterns suggest that the book is divided into two main parts $(1,12-6,9 ; 6,10-11,6)$ and the thought is also thus divided: in the first part Qoheleth is concerned with the vanity of various human endeavors, and in the second part with man's inability to understand the work of God.".

${ }^{8}$ Original em inglês: "The idea of the impossibility of understanding what God has done (which was always seen as $a$ theme) is in reality the theme, and it is built on the vanity motif prominent in the first part of the book.".

${ }^{9}$ A parte que tem arrancado cabelos de intérpretes é o entendimento da palavra "eternidade". Para um estudo mais detalhado, ver Leal e Castro Neto (2015).

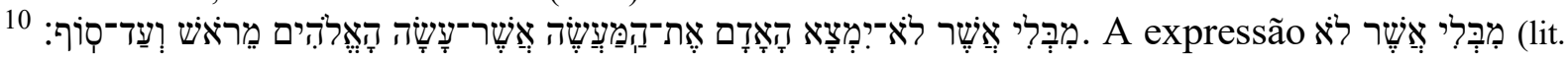
sem que não) é de difícil tradução, pois, como afirma Murphy (1992, p. 30), ela só é encontrada aqui em toda 


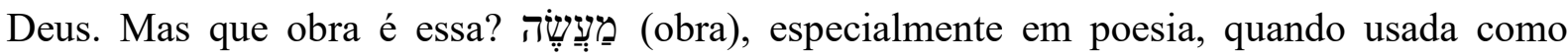
adjunto adnominal (construto) de Deus, refere-se ao governo (com objetivo de salvar) divino sobre o mundo (BOTTERWECK; RINGGREN; FABRY, v. 11, 2001, p. 399-401). Desse modo, Qohelet quer dizer que o homem não consegue perceber que Deus está conduzindo sua vida e por isso se aflige ${ }^{11}$.

Alguns autores são enfáticos ao falarem da impossibilidade de conhecimento divino por parte do ser humano, como Crenshaw (1987, p. 98) que afirma: "Qohelet observa que os humanos não podem, na verdade, compreender nada pertinente à atividade divina." ${ }^{12}$.

Outro texto que trata desse assunto em Eclesiastes é $8.17^{13}$. Esse texto complementa o que acabamos de dizer: todos os esforços humanos são ineficazes para o entendimento da vontade e atuação divina. Uma nota interessante é sugerida por Crenshaw (1987, p. 157) de que a obra que se faz debaixo do sol é obra de Deus. Mas isso será estudado adiante.

Ainda outro texto que fala da inescrutabilidade divina é $9.1^{14}$. É outro texto de difícil interpretação, especialmente na parte que nos interessa neste estudo, que é a parte final. A pergunta que nos aparece é: esse amor e ódio tem Deus como sujeito? A maioria dos comentaristas parece concordar que $\operatorname{sim}^{15}$. Porém, Krüger (2004, p. 168) e Líndez (1999, p. 350) afirmam que, provavelmente, esse amor e ódio seriam, na verdade, consequências das ações dos sábios e justos mencionados anteriormente. A ambiguidade surge do sufixo pronominal em לִפְניקֶם (diante deles). A quem eles se referem? Se estão se referindo ao homem (הָאָדָדם), então o desconhecimento do "amor e ódio" se refere às consequências de suas ações. Mas se estão se referindo ao "amor e ódio", então a maior probabilidade e de estarem se referindo ao amor e ódio de Deus.

literatura hebraica dos tempos bíblicos. Uma proposta que nós sugerimos e iremos seguir nessa análise é a usada na LXX, que traduz a expressão inteira por ő $\pi \omega \varsigma$ (para que), indicando finalidade.

${ }^{11}$ É interessante que esse texto faz referência à criação (Deus fez - 3.11a) e temos um paralelo interessante aqui: no relato das origens, o homem quis comer da árvore do conhecimento e o que veio a conhecer foi sua própria nudez (KRÜGER, 2004, p. 87). Da mesma forma, o texto mostra a incapacidade humana de conhecer a forma divina de trabalhar: nada do que façamos nos levará a esse conhecimento.

12 Original em inglês: "Qohelet observes that humans cannot really comprehend anything pertaining to divine acivity.".

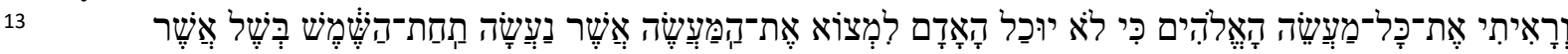
Tradução: E vi toda obra de Deus, pois não pode o homem alcançar a obra que é feita debaixo do sol, mesmo que se canse o homem para encontra-la não alcançará, e também se disser o sábio para conhecê-la, não poderá alcançar.

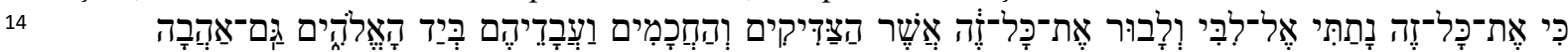
Tradução: De fato, tudo isto pus em meu coração para esclarecer tudo isto: que os justos e os sábios e suas obras estão na mão de Deus. Quer amor, quer ódio não há homem que conheça; tudo está diante deles.

${ }^{15}$ Os comentaristas que concordam que Deus é o sujeito do amor e do ódio são, entre outros: Longman III (1998, p. 227); Murphy (1992, p. 91); Whybray (1989, p. 140); Crenshaw (1987, p. 159). 
A gramática permite ambas ${ }^{16}$. A solução parece estar na proposta de Líndez (1999, p. 350): a ideia de Qohelet, como na maior parte de seu livro, é questionar a sabedoria tradicional (assim como Jó) da retribuição, seja divina seja natural. Em outras palavras, não é porque fazemos coisas boas que iremos recebê-las de volta, o homem não tem garantia de nada. A segunda posição, portanto, é a mais provável. As ações de Deus, dessa maneira, não apenas parecem ser, mas, de fato, são incompreensíveis, como nos revela o livro de Jó.

O último texto que fala da insondabilidade de Deus é $11.5^{17}$. O texto mostra como as ações de Deus são imprevisíveis e desconhecidas e o autor usa uma símile de duas coisas desconhecidas na época: o percurso do vento e a formação do bebê no útero de uma mulher. Deus é visto, então, como totalmente insondável.

Desse modo, Qohelet apresenta um Deus insondável, que está além da compreensão humana. Essa ignorância do homem com relação a Deus torna a vida, de certa forma, mera vaidade. Mas seguiremos em outro aspecto da teologia de Eclesiastes.

\subsection{A aparente arbitrariedade divina}

Qohelet apresenta a Deus como o Ser que está no controle de tudo. Isso fica evidente em várias passagens do livro. Um grupo dessas passagens apresenta Deus "dando" (כָתָן). É interessante que Deus é sujeito do verbo נָּתן (dar) em Eclesiastes doze vezes. Essa é a ação divina mais comum em Eclesiastes. E o que isso nos ensina? Stefanovic (2007, p. 47) afirma que esse verbo pode indicar que Deus tem pleno controle sobre as ações da história humana. Esse parece ser o caso: é Deus quem dá o trabalho $(1: 13 ; 2.26 ; 3.10)$, sabedoria, conhecimento e prazer $(2.26 ; 12.11)$; ignorância $(3.11)$; vida $\left(5.17 / 18^{18} ; 8.15 ; 9.9 ; 12.7\right)$; riquezas $(5.18 / 19$; 6.2). Em outras palavras, Deus está no controle desses eventos e características humanas: trabalho, sabedoria, ignorância, vida e riquezas.

Outros dois textos, já explanados anteriormente neste estudo, evidenciam isso: 8.17 e 9.1. Em 8.17, nós mencionamos a sugestão de Crenshaw (1987, p. 157) de que, observando o paralelismo do verso, percebe-se que a obra que se faz debaixo do sol é a obra de Deus. Em

\footnotetext{
${ }^{16}$ Waltke e O'Connor (2006, p. 303) afirmam que "[...] sufixos plurais podem ser usados depois de coletivos singulares.". Isso permite que o sufixo plural que aparece nessa palavra esteja se referindo ao substantivo singular (homem), pois ele está se referindo ao coletivo (humanidade).

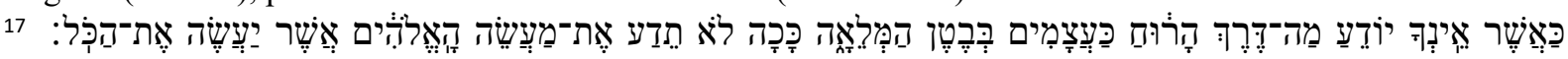
Tradução: Como não há para ti conhecedor de qual é o caminho do vento, ou como os ossos no útero se completam, assim não conheces a obra de Deus, que faz tudo.

183.17 na BHS e 3.18 na tradução de João Ferreira de Almeida Revista e Atualizada (ARA). Quando a versificação da ARA diferir da versificação da BHS, nós apresentaremos as duas opções separadas por barras. A primeira será sempre BHS e a segunda, sempre ARA.
} 
outras palavras, é Deus quem realiza as coisas debaixo do sol, o que evidencia um controle sobre o nosso mundo. E 9.1 afirma que tudo dos justos e sábios está nas mãos de Deus. Stefanovic (2007, p. 47) afirma que a palavra mão, no AT, é, muitas vezes, figurativa para poder e autoridade. Desse modo, o texto quer dizer que os justos e os sábios estão sob a autoridade divina.

Zuck (2009, p. 322) vê nisso uma soberania extrema, como predestinação divina, a soberania divina em detrimento da liberdade humana. Porém, Líndez (1999, p. 30) afirma que:

[...] em Qohélet observamos algumas precisões muito atinadas, que deixam muito claro tanto a liberdade de Deus em suas atuações como a do homem ao se dobrar às disposições divinas. Deus é soberano no exercício de seu governo (cf. 3,14; 7,13; 9,1); mas isso não faz periclitar a liberdade do homem que Qohélet supõe em muitas passagens (cf 3,16-17; 4,17-5,6; 7,29).

Para entendermos esse controle divino, devemos ter em mente a intertextualidade que Qohelet faz com o livro de Gênesis, especialmente Gn 4 (ANTIC, 2006, p. 203-211). Antic (2006, p. 203-211) faz um estudo de como Qohelet se baseia em Gn 1-4, especialmente Gn 4, para mostrar a vaidade da vida. Nisso, nós percebemos primeiro que Deus é Criador, por isso ele tem autoridade sobre suas criaturas. Segundo que o pecado fez o processo inverso do trabalho divino: destruir sua criação. É apenas com o pecado que a vida se torna vã, como afirma Aguiar (2014, p. 47) ${ }^{19}$. Mas Deus, mesmo em meio ao pecado, ainda assume o controle da história humana (Deus julga Caim, pois suas "aquisições" são vaidade). Ainda assim, coisas inesperadas acontecem (a morte de Abel - a vaidade da vida). Mas Deus dá um substituto: Sete.

Essa intertextualidade com Gênesis, portanto, nos ensina que o foco do controle de Deus no mundo é seu julgamento ${ }^{20}$. E esse julgamento pode ir além do período da vida. Esse será o foco da segunda parte de nosso estudo.

Desse modo, a aparente "arbitrariedade" de Deus está mais relacionada com a incompreensão que temos em relação a Ele e suas obras do que com uma predestinação d'Ele para conosco.

Essa visão de Qohelet está bem relacionada com o que podemos observar da vida. Pondé (2010, p. 111-125) afirma que a vida não tem sentido porque há injustiças no mundo.

\footnotetext{
${ }^{19}$ Falando da intertextualidade de Eclesiastes com Gênesis, Aguiar (2014, p. 46-47) mostra como a afirmação de Ec 1.3 (com que se afadiga debaixo do sol) remete a Gênesis 3.17. Desse modo, o livro de Eclesiastes vê a vida após o pecado. Um outro texto que deixa esse assunto mais claro é Ec 7.29, onde mostra Deus criando o homem perfeito, mas ele acaba estragando tudo.

${ }^{20}$ Assim como em Gênesis, no juízo sobre Caim, o livro de Eclesiastes traz a justiça e juízo divino como base para suas ações, como veremos na próxima parte do trabalho.
} 
Essa injustiça, segundo ele, decorre do fato de que parecemos viver governados por um destino, onde o que acontece conosco não está baseado exatamente naquilo que fazemos. E o pior é que, esse destino (a aparente arbitrariedade da qual Qohelet fala) parece ser totalmente sem sentido. Parafraseando o filósofo Lucrécio, Pondé (2010, p. 120) afirma que a natureza das coisas é não ter natureza alguma. Sendo assim, não há sentido no mundo quando o observamos. E, por isso sofremos. "Não sofremos apenas com o acaso em si, mas com a relação afetiva que temos com ele: temos medo da violência cega que ele implica ao anular todo o valor de nossa agonia em busca de um mundo suficiente.” (PONDÉ, 2010, p. 121). Por isso, ele pode dizer que "Nunca seremos plenamente realizados em nada.".

Essa é a mesma conclusão a que Qohelet chega ao dizer que tudo é vaidade. Ele descreve que Deus atua no mundo, mas que não podemos compreender plenamente sua atuação (3.11) e essa incompreensão torna a vida sem sentido. Tendo Deus como Criador e Soberano do mundo, suas ações é que dão sentido ao mundo, porém, o homem não pode compreendê-la e, portanto, não pode compreender o sentido do mundo. Mas, em meio às águas do sem-sentido, Qohelet consegue levantar a cabeça para tomar fôlego de um ar que está além da observação: o modo como Deus pode dar sentido a tudo.

Nesta primeira parte, vimos que Deus é insondável e isso O faz parecer arbitrário, mas apenas evidência nossa ignorância. O desconhecimento humano das ações divinas e sua aparente arbitrariedade tornam a vida sem sentido algum: tornam-na vaidade. Mas, a seguir, veremos que o livro de Qohelet não termina assim, tão sem sentido e arbitrário: há um sentido na vida.

\section{Deus atuante - a teologia do epílogo (12:9-14)}

Uma parte com a qual as interpretações dos estudiosos do livro de Qohelet não concordam é o epílogo (12.9-14). A grande maioria considera o epílogo como sendo obra de um editor posterior. A argumentação de cada teólogo é variada. Barton (1980, p. 44) crê que a mudança de pessoa no v. 8 com os vv. precedentes e do v. 8 com os seguintes é o indicativo do trabalho de um editor. Scott (1979, p. 256) afirma que a expressão “diz o Pregador" (1.2 e 12.8) formam o livro principal, o restante se torna acréscimo. Krüger (2004, p. 208), por sua vez, afirma que essa divisão aparenta duas pessoas inserindo conteúdo no livro, mas não exclui a possibilidade de se tratar de apenas uma pessoa que inseriu dois tipos de conteúdo no livro. Crenshaw (1987, p. 189) e Líndez (1999, p. 413) creem haver dois epílogos, obra de dois epilogistas. Fox (1977, p. 83-106) argumenta, seguido por Krüger (2004, p. 208), que 
não se trata de edições e nem de adições, mas do trabalho de um mesmo autor que pretendeu colocar duas vozes no livro, como um autor que quer apresentar os dois lados de uma mesma moeda.

Mas a divisão com relação ao epílogo aumenta quando tentamos entender seu papel diante de todo o livro. Scott $(1979$, p. 256) afirma que o epílogo tenta amenizar as divisões dentro do próprio texto de Eclesiastes. Crenshaw (1987, p. 190) crê que o segundo epílogo (12.12-14) é "[...] um desmerecedor que pensa dos ensinos de Qohelet como inadequados e, talvez, perversos." ${ }^{21}$. Krüger (2004, p. 208) pensa que, provavelmente, o epílogo trata-se de uma ironia do próprio autor de Eclesiastes. Líndez (1999, p. 420) vê o segundo epílogo como as exposições da crença desse segundo epilogista, não necessariamente concordando com o restante do livro. Longman III (1998, p. 274) afirma que o epílogo concorda em parte com o restante do livro e critica outras partes. Whybray (1989, p. 169), por sua vez, diz que o primeiro epílogo (12.9-11) conclui a obra de Qohelet sem críticas enquanto o segundo apresenta aquilo que o epilogista acredita ser mais importante que o restante do livro: temer a Deus e guardar seus mandamentos. Shields (1999, p. 117-139) afirma que o epílogo serve como confirmação das observações de Qohelet e, consequentemente, como uma crítica à sabedoria em si.

Mas a visão que vamos adotar aqui (daremos os motivos mais à frente) é a de Shead (1997, p. 67-91). Shead (1999, p. 117-139) afirma que o epílogo é chave interpretativa do livro. Dillard e Longman III (2005, p. 243) concordam com ele ao afirmar que: "Para entender Eclesiastes, portanto, é necessária a leitura muito atenta do epílogo.”. Nós exporemos cinco argumentos com os quais mostraremos que o epílogo não só está em sintonia (fala do mesmo assunto) com o restante do livro, como ele também é uma conclusão apropriada e pode nos ajudar a entender o restante do livro.

O primeiro argumento tem a ver com a estrutura do livro. Já mostramos que a ideia de Wright (1968, p. 313-334) parece ser nossa melhor opção. Em outro artigo, o mesmo autor (1980, p. 38-51) mostra argumentos numéricos para sua teoria. O livro inteiro de Eclesiastes possui 222 versos, a metade disso, 111, terminaria exatamente onde termina a primeira seção do livro (6:9). E a segunda metade começa onde começa a segunda seção do livro $(6: 10)^{22}$. Para que essa unidade numérica permaneça, o epílogo deve continuar onde está: fazendo parte

\footnotetext{
${ }^{21}$ Original em inglês: “[...] a detractor who thinks of Qohelet's teachings as inadequate and perhaps perverse.".

${ }^{22}$ Outros argumentos são expostos em Wright (1980, p. 38-51), que não serão descritos aqui por razão de espaço. 
do livro. Pois só com ele é que a contagem faz sentido. Isso ajuda a mostrar que o epílogo foi premeditado para fazer parte do livro e o livro foi premeditado para ter esse epílogo.

O segundo argumento para o uso do epílogo como ferramenta para uma correta interpretação do restante do livro se relaciona com as próprias bases da hermenêutica. Sem dúvida há uma inclusão (inclusio) entre Ec 1.2 e 12.8. Por isso, muitos como Shields (1999, p. 123) afirmam que o epílogo é uma adição posterior à obra e, provavelmente em nada relacionada com ela. Porém, Stuart (2008, p. 40) afirma que, quando há singularidades (e quase sempre há) em questões de estilo e forma, o que aparece diferente deve ser destacado, pois o autor quis dar maior importância. Esta ideia é nossa visão sobre a unidade do livro, as partes que parecem fugir à estrutura comum são as que merecem maior atenção na exegese. $\mathrm{O}$ epílogo, no caso do livro de Eclesiastes, é uma dessas partes que merecem atenção na exegese, pois foge a uma estrutura básica do livro: a inclusão de 1.2-12.8.

O terceiro argumento é resultante da exegese do próprio epílogo e é apresentada por Shead (1997, p. 70) que afirma que a expressão סוֹף (traduzido por Almeida (1993, p. 703) como "suma de tudo"; lit. fim da palavra/coisa) indica que a conclusão de tudo o que foi de dito antes leva ao que será dito a seguir. Portanto, essas palavras querem dizer que, realmente, o epílogo é um grande auxílio para o entendimento de Eclesiastes. Mas aqui aparecem muitas controvérsias.

A crítica mais direta ao trabalho de Shead (1997) é a de Shields (1999). Shields (1999, p. 123), ao contrário de Shead, diz que palavra (רדฺฺָ̣) não remete ao restante inteiro do livro, pois o livro inteiro, segundo ele, não pode ser resumido apenas na afirmação "Teme a Deus e guarda seus mandamentos". Ainda segundo ele, רָָָ está se referindo não a um resumo, mas como literalmente o texto diz: a última palavra (ou coisa).

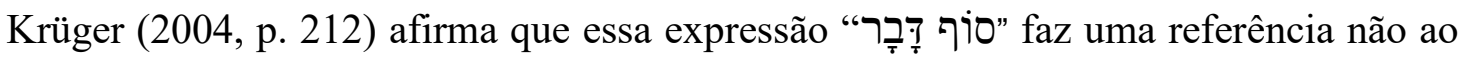
próprio livro, mas a outros livros. Para Líndez (1999, p. 419), esta expressão significa mesmo conclusão, mas não do livro todo como podemos ser levados a pensar, mas apenas do próprio epílogo. Mas para Whybray (1989, p. 173), essa expressão significa a conclusão do livro como um todo. Doukhan (2006, p. 125) acredita que essa expressão indica uma conclusão não só Eclesiastes, mas de tudo o que se pode dizer sobre a vida. Então, para resolvermos essa disparidade de opiniões, devemos analisar a relação do epílogo com o restante do livro, para sabermos se ele é mesmo um resumo do livro. Para isso, vamos ao quarto argumento.

$\mathrm{O}$ quarto argumento tem a ver com a terminologia. As palavras que Qohélet usa no epílogo são 74, destas, 58 aparecem no restante do livro o que pode ser pouco em relação ao 
total de palavras que são 2997, o que representariam 1,9\%. Porém, as palavras que aparecem em ambas as partes do livro se repetem com tamanha intensidade que ocupariam 29,5\% das 2997 palavras do livro. As 15 palavras que não se repetem no livro aparecem pouquíssimas vezes no AT, o que mostra uma seleção importante feita por Qohélet para finalizar o livro (SHEAD, 1997, p. 72-73).

O último argumento também tem a ver com a terminologia, mas não na quantidade de uso, como o quarto argumento, mas sim na qualidade dos termos. $\mathrm{O}$ autor do livro tinha o costume de usar palavras incomuns ao restante do Antigo Testamento para determinar seu pensamento. Essas palavras são "favoritas", pois ajudam a manter a organização e a unidade da obra. Qohelet as repete no epílogo para mostrar uma unidade de ideias entre o corpo da obra e a sua conclusão. Segundo Shead (1997, p. 74-75, tradução nossa),

[...] essas palavras de 12.9-14 realizam uma função específica em Eclesiastes: elas forjam links alusivos entre o epílogo e o material anterior que tem o mesmo vocabulário. [...] Em outras palavras o epílogo é particularmente retrospectivo de certas partes do livro e isso sugere que o epílogo está, de algum modo, interagindo com tais passagens, se pelo modo de comentário implícito ou, talvez, alusão por motivo de reiterar a mensagem das seções em questão. ${ }^{23}$

Shields (1999, p. 123), porém, rebate essa ideia de que o link verbal possa ser usado como base para perceber a relação entre o epílogo e o restante do texto. Segundo ele, "Não é suficiente estabelecer a presença de conexão verbal dentro do texto, é necessário estabelecer o significado dessa conexão."24 . Para satisfazer essa exigência levantada por Shields (1999, p. 123ss) (exigência legítima, diga-se de passagem), de que é preciso estabelecer o significado da conexão verbal, nós examinaremos alguns textos dentro do corpo do livro de Eclesiastes cujo sentido se relaciona especialmente com a segunda parte do epílogo (12.12-14) ${ }^{25}$.

Um trecho de Eclesiastes que se relaciona muito com 12.13-14 é 3.17-18 ${ }^{26}$, que é outro texto de interpretação problemática. Longmann III (1998, p. 127-128) acha que, nesta passagem, Qohelet está citando uma afirmação de sua tradição religiosa (Deus julgará o

\footnotetext{
${ }^{23}$ Original em inglês: "Therefore these words from 12:9-14 perform a specific function in Ecclesiastes: they forge allusive links between the epilogue and earlier material that has the same vocabulary. [...] In other words, the epilogue is particularly reminiscent of certain parts of the book, and this suggests that the epilogue is in some way interacting with such passages, whether by way of implicit commentary, or perhaps allusion for the sake of reiterating the message of the sections in question."

24 "It is not enough to establish the presence of a verbal link within the text, it is necessary to establish the significance of that link."

${ }^{25}$ A razão de termos escolhido a segunda parte do epílogo para relacionar com o restante do livro é que é justamente essa parte da qual se afirma que é contrário ao restante do livro. A primeira parte do epílogo (12.911) é aceita, pela grande maioria dos estudiosos, como concordante com o restante do livro.

${ }^{26}$ Alguns estudiosos afirmam que este verso é uma interpolação feita pelo epilogista, que seria uma pessoa diferente de Qohelet (cf. Whybray, 1989, p. 77). 
mundo) e questionando-a (pois há um tempo - os versos seguintes mostram que este tempo de juízo nunca chega). Whybray (1989, p. 77-78), por outro lado, não vê uma crítica à tradição religiosa de Qohelet, mas, antes, uma afirmação do desconhecimento de quando o tempo de julgamento chegará. Líndez (1999, p. 239-242) mostra que realmente há um juízo justo de Deus, que seria a solução para esses problemas todos.

De qualquer forma, Ec 3.17-18 não é um acréscimo posterior de um editor. Como afirma Krüger (2004, p. 91), a segunda metade do verso 17 não permite que seja uma edição. Com isso, podemos estar certos de que o tema do juízo e do tempo do juízo (que é desconhecido aos seres humanos) é pertinente ao argumento de Qohelet. Assim, podemos concluir que o epílogo tem relações temáticas com o restante do livro, especialmente com esse verso.

Mas, a que tipo de juízo o texto está se referindo? Krüger (2004, p. 91) afirmou a possibilidade de que este julgamento seja escatológico, ou após a morte do indivíduo. Isso aflige a vida debaixo do sol, porque não é aqui que as coisas vão ficar bem.

Para responder corretamente à pergunta acerca do tipo de juízo, é necessário saber se a

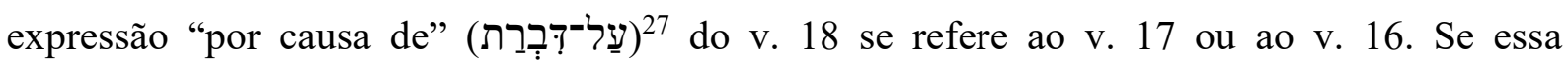
expressão se refere ao v. 17, então o juízo é a morte, porque a morte, no v. 19 é vista como a razão de os homens serem iguais aos animais e no v. 18, afirma-se que é o juízo. Se essa expressão está se referindo ao v. 16, então não é do juízo que está tratando e o juízo significaria, provavelmente, algo escatológico.

A função do marcador frasal "disse eu em meu coração" nos ajudará a resolver esse impasse. Percebe-se nessa pequena perícope $(3.15 \mathrm{ss})$ que esse marcador tem a função de conclusão ou comentário do que foi dito anteriormente (no caso, sobre a injustiça que ocorre

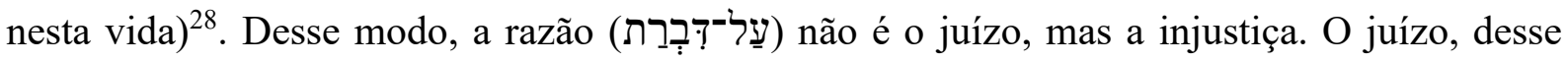
modo, é algo que acaba com a injustiça, mas, como não o vemos agora (nem mesmo Qohelet o vê) ele deve ser escatológico.

Outra passagem que remete à ideia do epílogo é 11.9. A maioria dos comentaristas crê ser este verso um acréscimo posterior para harmonizar o texto com Nm 15.39. A tradução da Almeida Revista e Atualizada foi um tanto infeliz ("Deus te pedirá contas”). A expressão

${ }^{27}$ Essa é uma expressão, provavelmente, enfática, já que Waltke e O’Connor (2006, p. 218) afirma que a

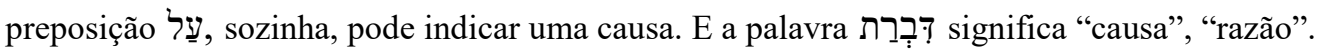

${ }^{28}$ Algo que algumas traduções não permitem notar é que a expressão que inicia o v. 17 é exatamente a mesma

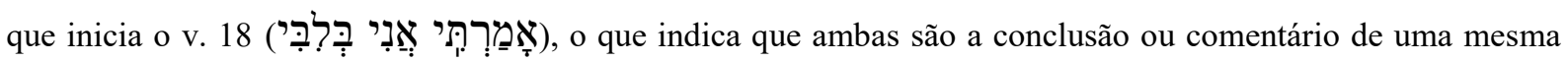
ideia. 
hebraica é, praticamente, a mesma de $12.14^{29}$. Krüger (2004, p. 197) acha que o julgamento divino é justamente a transitoriedade da vida. O julgamento de Deus aqui, pelo contexto (v. 8$10 ; 12.1-7)$, parece ser mesmo a transitoriedade da vida e o próprio envelhecer, mas é preciso lembrar, junto com Eaton (1989, p. 153-154) que há várias formas de Deus julgar o ser humano.

Assim, com duas passagens, fica evidente que o juízo é um tema pertinente ao pensamento de Qohelet, e não acrescentado por um editor epilogista num período posterior. Além dessas duas passagens controversas que apresentamos, Shead (1999, p. 84-86) apresenta o texto de Ec 7.23-8.1 e argumenta que justiça e juízo, além de outros temas apresentados no epílogo também são apresentados ali. Desse modo, em pelo menos três passagens, o tema do juízo, defendido pelo epílogo aparece no corpo do livro. Mas, além desse tema, temos outros, como o temor do Senhor (12.13), que também aparece no restante do livro $(3.14 ; 5.6 ; 7.18$; $8.12,13)^{30}$.

Desse modo, podemos concluir que o epílogo não é contrário ao restante do livro, nem uma tentativa de amenizá-lo, mas uma perfeita conclusão da obra que nos leva a entendê-la melhor. E, já que o epílogo de Eclesiastes nos ajuda a entender esse complexo livro, resta-nos, para o interesse de nosso trabalho, a pergunta: como Deus é apresentado no epílogo? De duas formas: como Doador da sabedoria (12.11) e como Juiz (12.13).

Com relação ao primeiro modo como Deus é apresentado no epílogo, Fox (1977, p. 102) argumenta que Deus não é o pastor representado em Ec 12.11. Para sustentar sua ideia, ele dá dois argumentos: Deus é chamado de pastor no AT apenas com relação à sua atuação como mantenedor e salvador; e o numeral "um" no final do verso (צָ) tem a função de artigo indefinido e não numeral. Porém, iremos discordar dessa visão e concordar com a ideia tradicional de que o pastor apresentado em Ec 12.11 não é "um pastor", mas "o único Pastor". Isso porque, o primeiro argumento de Fox não é forte: o ato de dar palavras aos sábios indica uma manutenção (Deus como mantenedor) da parte de Deus e justifica o uso da palavra "pastor". O segundo argumento também é fraco sozinho, pois também pode indicar um numeral, não necessariamente um artigo indefinido, como se pode ver em Dt 6.4 .

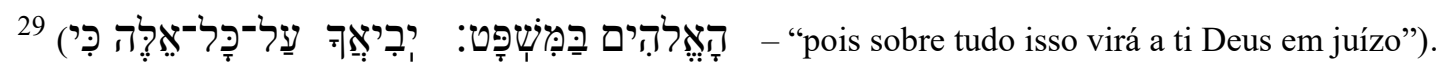

${ }^{30}$ Doukhan (2006, p. 125) afirma que "guardar os mandamentos" aqui é uma explicação para o "temor do Senhor". 
Além disso, a ideia de Deus doando sabedoria é tema básico dos livros sapienciais (VON RAD, p. 53-73) ${ }^{31}$. Desse modo, podemos ver, neste texto, Deus como doador da sabedoria.

A outra noção de Deus é apresenta-lo como juiz, atestada em 12.13. Porém, que tipo de juiz Deus é? A resposta está no corpo do livro. Um estudo feito por Shead (1997, p. 89) no texto de Eclesiastes 7.23-8.1 mostra que este texto apresenta três níveis de obra

Em outras palavras, há o nível (1) das aparências, o modo que as coisas parecem para o observador. Depois, há o nível (2) da atividade que nós deveríamos fazer. Nesse nível está o chamado para o regozijo e o comportamento justo. E há o nível

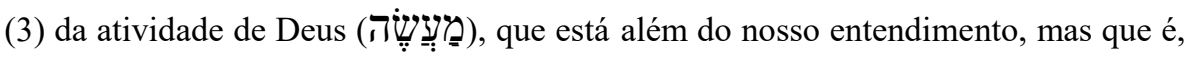
não obstante, em última instância, justa (טְִ̣̣). ${ }^{32}$

Desse modo, podemos perceber que Deus é um juiz justo. Não é um juiz que julga arbitrariamente, mas um juiz que julga retamente. E esse juízo que Deus trará parece ser a esperança de Qohelet $(3.17 ; 12.13)$. Essa é uma premissa da literatura sapiencial. Não o juízo em si, mas uma atuação futura de Deus. Von Rad (1972, p. 202-203) mostra que diante de situações difíceis, a sabedoria ensinava a confiar que Deus iria atuar e, quando Ele não parecia que iria atuar, a sabedoria ensinava a esperar no Senhor, ou melhor, esperançar no Senhor. É o que Qohelet está fazendo aqui: a vida é vaidade, mas devemos confiar ou esperar o juízo de Deus, porque Ele é justo. Comentando sobre a expectativa do juízo no livro de Eclesiastes, Aguiar (2014, p. 43) diz que

Embora essas palavras possam soar ameaçadoras, em última instância elas revelam a compreensão do Qoheleth de que nem tudo termina aqui. Embora o seu existencialismo também concorde que se deve viver bem o aqui e agora, há uma expectativa de algo promissor saltando do texto.

Assim, o fato de Deus ser apresentado como juiz em Eclesiastes indica que, diante da falta de sentido na vida, há um sentido: o juízo de Deus. Esse juízo de Deus dá sentido a vida porque ele, justamente, vai resolver e acabar com todas as injustiças. Mas fica uma interrogação: porque duas visões sobre Deus aparentemente tão contrastantes? Nós vimos na

\footnotetext{
${ }^{31}$ Shields (1999, p. 117-139) contestaria dizendo que Qohelet tenta desconstruir a sabedoria tradicional, o que não é, de todo errado, mas não é, também, de todo certo. Qohelet questiona o valor da sabedoria e sua base (Ec 2.12-17, etc.), mas ele ainda acredita nos valores sapienciais (Ec 7.11, 12, 19, etc.).

${ }^{32}$ No original: "In other words, there is the level (1) of appearances, the way things look to the observer. On this level is vanity and evil. Then there is the level (2) of activity, the way we should live. On this level is the call to

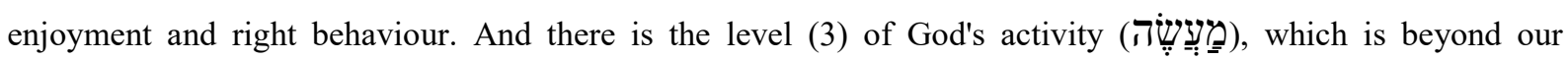
understanding but nevertheless ultimately just (טְִ̣̣)." 
primeira seção deste artigo que, para Qohelet, Deus é incompreensível e distante, mas nesta segunda seção, o próprio Qohelet $\mathrm{O}$ apresenta como atuante e justo. Será que é possível harmonizar essas duas visões que Qohelet dá sobre Deus? Qual foi seu objetivo ao fazer isso? Veremos a seguir.

\section{A harmonia das visões em qohelet e a visão bíblica sobre deus}

A harmonia entre as duas visões aparentemente contrastantes de Qohelet (um Deus distante e insondável e um Deus que atua através do juízo) se dá pelo trabalho de Fox (1977, p. 83-106), onde é evidenciado que o livro de Eclesiastes tem duas vozes, não dois autores ${ }^{33}$. Em outras palavras, Qohelet apresenta duas perspectivas: uma dominada pelo empirismo (o que Qohelet pode ver e experimentar) e a outra dominada pela fé.

Ao terminar um livro profundamente heterodoxo com afirmações ortodoxas, o autor criou uma certa ambiguidade. Ele permitiu ao leitor escolher a qual voz se aproximaria com mais proximidade, a de Qohelet [o corpo do livro] ou a do epilogista. (FOX, 1977, p. 105, acréscimo nosso).

Este texto mostra que era propósito do autor de Eclesiastes colocar duas visões distintas, mas, diferentemente de Fox (1977, p. 105), nós percebemos que o epílogo está em harmonia com o restante do livro, primeiro pelas razões citadas acima sobre o relacionamento entre o epílogo e o corpo. Segundo porque von $\operatorname{Rad}(1972$, p. ) afirma que as contradições entre a vida e a fé, para a literatura sapiencial eram resolvidas com a esperança. Essa esperança, de acordo com Martin-Achard (2015, p. 234), pode ser após a morte, numa ressurreição seguida de juízo, como ele afirma:

Em conclusão, para o crente a vida não tem nenhum sentido se Yahweh não é justo. Portanto, exigirá que a justiça divina, negada atualmente sem cessar, se realize amanhã, e uma vez que se negue a perder a esperança nela, chegará a proclamar o retorno dos mortos à vida.

Observaremos mais à frente que a "sorte" que é igual a todos, motivo de injustiça, não é o juízo divino, Qohelet prega sobre outro juízo que irá, justamente, julgar a todos para que a "sorte" não seja igual, mas seja justa ${ }^{34}$. Assim, o que Qohelet quer mostrar é, na verdade, que

\footnotetext{
${ }^{33}$ Fox (1977, p. 83-106) dá exemplos de como isso acontece em outros textos, inclusive não-bíblicos.

${ }^{34}$ Qohelet não fala apenas do problema da injustiça. São vários motivos pelos quais "tudo é vaidade". Mas a injustiça é um dos principais (PONDÉ, 2010, p. 11-125). Além disso, se entendido da perspectiva de MartinAchard (2015) que envolve a ressurreição, todos os problemas tratados no livro seriam resolvidos pelo juízo. 
a vida tal como nos apresentada, não tem sentido especialmente por causa da injustiça, mas que devemos confiar, ter esperança, de que Deus julgará a todos e, desse modo, aplicará a justiça definitivamente.

Com essa visão sobre Deus, Qohelet concorda com o restante do Antigo Testamento, em especial com os escritos sapienciais, com Daniel (DOUKHAN, 2006, p. 126) e com os escritos legais. Nos escritos sapienciais, particularmente, Jó e os salmos 37, 49 e 73, mostram que há uma injustiça na terra. Em especial, Jó dá entender que essa injustiça se dá pela insondabilidade de Deus (nem no começo nem no final do livro Jó consegue entender o que Deus está fazendo ou permitindo). Os salmos 37, 49 e 73 mostram que Deus irá resolver o problema da injustiça por um juízo definitivo (MARTIN-ACHARD, 2015, p. 176).

O nome Daniel significa “Deus é meu juiz". Só o título do livro apocalíptico do AT já indica sua relação com Eclesiastes ${ }^{35}$. Porém, o primeiro capítulo mostra Deus conduzindo soberanamente os acontecimentos mesmo que não pareça, também, indica também uma relação de ideias com Eclesiastes, que mostra um Deus incompreensível em suas ações (STEFANOVIC, 2007, p. 47). Por último, o capítulo sete de Daniel mostra a injustiça que ocorre com o povo de Deus durante "um tempo, tempos e metade de um tempo" e como isso é resolvido através do juízo (SHEA, 2007, p. 147-148).

Schmidt (2004, p. 138-155) mostra como os mandamentos revelam um Deus transcendente (inimaginável e acima de toda a criação - proibição de fazer imagens), mas, ao mesmo tempo, mostram um Deus que atua na história humana ("que te tirou da terra do Egito"). Essa visão aparentemente paradoxal, portanto, de um Deus cujas obras são incompreensíveis, mas que é visto atuando (segundo Eclesiastes, pelo juízo) percorre todo o AT até o livro apocalíptico (Daniel). Desse modo, a maneira como Eclesiastes apresenta Deus está em harmonia com o restante do Antigo Testamento.

\section{Considerações Finais}

Este trabalho procurou analisar o modo como Deus é descrito no livro de Eclesiastes. Vimos que o autor do livro apresenta duas visões aparentemente diferentes e contraditórias. De forma geral, ele apresenta a Deus como distante, incompreensível e insondável. Mas, dá

\footnotetext{
${ }^{35}$ É interessante notar que Osborne (2009, p. 352) afirma que "[...] o apocaliptismo teve, na sua origem, tanto influência profética quanto sapiencial [...]". Desse modo, o livro de Daniel está intimamente ligado a Eclesiastes porque este faz parte do corpus sapiencial que influenciou o corpus apocalíptico, do qual aquele faz parte.
} 
pistas durante o livro de algo que seria explicitado no epílogo: Deus resolverá os problemas apresentados durante o corpo do livro num juízo. As duas visões são, portanto, complementares. Primeiro, Qohelet apresenta o problema: a falta de sentido pela aparente arbitrariedade na atuação de Deus nesta Terra. Depois, ele apresenta a solução: Deus trará juízo sobre o que acontece sobre a Terra.

Depois de apresentarmos isso mostramos que essa visão de Deus concorda com o restante da visão veterotestamentária sobre seu Deus. Em especial, os livros sapienciais, dos quais Eclesiastes faz parte do corpus, os textos legais do AT e o livro de Daniel têm uma visão muito semelhante sobre a divindade. Em outras palavras, um Deus que tolera a injustiça por um tempo, mas que acabará com ela através de um julgamento.

Cremos que muito pode ser acrescentado sobre esse tema e outros aspectos da teologia geral de Eclesiastes, como sua doutrina do homem, da morte e outras.

\section{Referências}

AGUIAR, Adenilton Tavares de. O evangelho de Tiago: sabedoria e piedade em favor dos pobres. Santo André: Academia Cristã, 2014.

ANTIC, Radiša. Cain, Abel, Seth, and the meaning of human life as portrayed in the books of Genesis and Ecclesiastes. Andrews University Seminary Studies, v. 44, n. 2, p. 203-211, 2006.

BARTON, George Aaron. A critical and exegetical commentary on the book of Ecclesiastes. Edinburgh; T and T, 1980.

CERESKO, Anthony R. A sabedoria no Antigo Testamento: espiritualidade libertadora. São Paulo: Paulus, 2004.

CLIFFORD, Richard J. The wisdom literature. Nashville: Abingdon Press, 1998.

CRENSHAW, James. Ecclesiastes: a commentary. Philadelphia: The Westminster Press, 1987. (The Old Testament Library).

DILLARD, Raymond B.; LONGMAN III, Tremper. Introdução ao Antigo Testamento. São Paulo: Vida Nova, 2005.

DOUKHAN, Jacques B. Ecclesiastes: all is vanity. Nampa: Pacific Press, 2006.

EATON, Michael A. Eclesiastes: introdução e comentário. São Paulo: Vida Nova, 1989. (Série Cultura Cristã). 
FOX, Michael V. Frame-narrative and composition in the book of Qohelet. Hebrew Union College Annual, n. 48, p. 83-106, 1977.

GILBERT, Pierre. Fighting fire with fire: divine nihilism in Ecclesiastes. Direction, n. 40, v. 1, 2011, p. 65-79.

KRÜGER, Thomas. Qoheleth. Minneapolis: Fortress Press, 2004. (Hermeneia - a critical and historical commentary on the Bible).

LEAL, Jônatas de Mattos; CASTRO NETO, José Carlos Camillo. Eternidade no coração do homem? Uma análise exegética de Eclesiastes 3.11. Revista Hermenêutica, v. 16 (n. 1), p. $27-$ 42, 2016.

LÍNDEZ, José Vílchez. Eclesiastes ou Qohélet. São Paulo: Paulus, 1999.

LONGMANN III, Tremper. The book of Ecclesiastes. Grand Rapids: William B. Eerdmans Publishing Company, 1998. (The new international commentary on the Old Testament).

MARTIN-ACHARD, Robert. Da morte à ressurreição segundo o Antigo Testamento. Santo André: Academia Cristã, 2015.

MIDDLETON, Darren J. N. Qoheleth's theology of transience: a homily. Encounter, n. 66, v. 4, 2005, p. 361-363.

MILLER, Douglas B. What the Preacher forgot: the rhetoric of Ecclesiastes. The Catholic Biblical Quarterly, n. 62, 2000, p. 215-235.

MOSKALA, Jiri. A fresh look at two Genesis creation accounts: contradictions? Andrews University Seminary Studies, v. 49, n. 1, 2011, p. 45-65.

MURPHY. Roland E. Ecclesiastes. Dallas: Word Books, 1992. (Word Biblical Commentary, v. 23a)

OKORIE, A. M. Understanding the book of Ecclesiastes. African Ecclesial Review, n. 39, v. 1, outono de 1997, p. 53-57.

OSBORNE, Grant R. A espiral hermenêutica: uma nova abordagem à interpretação bíblica. São Paulo: Vida Nova, 2009.

PETERSON, Eugene H. A mensagem: Bíblia em linguagem contemporânea. São Paulo: Editora Vida, 2011.

PINTO, Carlos Osvaldo Cardoso. Foco e desenvolvimento no Antigo Testamento: estruturas e mensagens dos livros do Antigo Testamento. São Paulo: Hagnos, 2006.

PONDÉ, Luiz Felipe. Contra um mundo melhor: ensaios do afeto. São Paulo: Leya, 2010.

SCOTT, R. B. Y. Proverbs and Ecclesiastes: introduction, translation and notes. New York: Doubleday \& Company, 1965. (Anchor Bible Commentary). 
SHEA, William. Estudos selecionados em intepretação profética. 2. ed. Engenheiro Coelho: UNASPRESS, 2007.

SHEAD, Andrew. Reading Ecclesiastes ‘epilogically'. Tyndale Bulletin, n. 48, v. 1, 1997, p. 67-91.

SHIELDS, Martin A. Ecclesiastes and the end of wisdom. Tyndale bulletin, n. 50, v. 1, 1999, p. 117-139.

SCHIMDT, Werner H. A fé do Antigo Testamento. São Leopoldo: Sinodal, 2004.

STEFANOVIC, Zdravko. Daniel, wisdom to the wise: commentary on the book of Daniel. Nampa: Pacific Press, 2007.

STUART, Douglas. Antigo Testamento. In: STUART, Douglas; FEE, Gordon D. Manual de exegese bíblica: antigo e novo testamentos. São Paulo: Vida Nova, 2008.

VON RAD, Gerhard. Wisdom in Israel. Nashville: SCM Press, 1972.

WALTKE, Bruce K.; O'CONNOR, Michael P. Introdução à sintaxe do hebraico bíblico. São Paulo: Cultura Cristã, 2006.

WHYBRAY, R. N. Ecclesiastes. Grand Rapids: Wm. B. Eerdmans Publishing Company, 1989. (The new century Bible commentary).

WRIGHT, Addison G. The riddle of the sphinx: the structure of the book of Qoheleth. The Catholic Biblical Quarterly, v. 30, n 3, p. 313-334, julho 1968.

The riddle of the sphinx revisited: numerical patterns in the book of Qoheleth. The Catholic Biblical Quarterly, v. 42, n. 1, p. 38-51, janeiro 1980.

ZUCK, Roy B. Uma teologia dos livros sapienciais e cantares de Salomão. In: ZUCK, Roy B. (ed.). Teologia do Antigo Testamento. Rio de Janeiro: Casa Publicadora das Assembleias de Deus, 2009. 